\title{
The Influence of Intellectual Capital Components to Financial Performance and Value of the Firm Registered in Indonesia Stock Exchange
}

\author{
Budiandriani $^{1, *} \&$ Mahfudnurnajamuddin ${ }^{2}$ \\ ${ }^{1}$ School of Economics Tri Dharma Nusantara Makassar, Indonesia \\ ${ }^{2}$ Faculty of Economic, University of Muslims Indonesia Makassar, Indonesia \\ *Corresponding author: School of Economics Tri Dharma Nusantara Makassar, Indonesia \\ E-mail: budiandriani@yahoo.com
}

Received: January 25, 2014 Accepted: March 24, 2014 Published: March 31, 2014

doi:10.5296/rae.v6i1.5400ＵRL: http://dx.doi.org/10.5296/rae.v6i1.5400

\begin{abstract}
This study aims to analyze the influence of intellectual capital components consisting of value added capital employed, value added human capital, and value added structural capital to financial performance and value of the firm, as well as financial performance to value of the public firm registered in Indonesia Stock Exchange. This study is concerned with companies registered in Indonesia Stock Exchange, by 158 samples of 464 firms which are registered in 2012.Data is analyzed by using Path Analysis Model by means of program AMOS version 18.The findings show that each of intellectual capital components consisting of value added capital employed and value added structural capital give positive and significant effect on capital performance and value of the firm. Although value added human capital gives positive effect, it does not significantly affect financial performance and value of the firm; then, financial performance affect positively and significantly value of the firm registered in Indonesia Stock Exchange. It can give signal to investors to invest in the firm in purpose to gain return. High and low rates of return which will be received by investors reflects value of the firm.
\end{abstract}

Keywords: intellectual capital components, corporate governance mechanism, financial performance, and value of the firm 


\section{Introduction}

Capital market in Indonesia is rapidly developed either in form of stock or debt instrument. Investors investing their fund in capital market are not only having short-term purpose, but also obtaining long-term income. Accordingly, the investors should utilize all information to analyze the market and its investment in expectation to gain profit.

Generally, goal of the firm is to maximize stakeholder value through dividend policy and price improvement of the firm's stock market. The firm desires a presence of growth therein, while on the other side, it should also be able to pay the dividend to investors; unfortunately these two objectives are in contradiction. The firm prefers to hold the profit to divide it in form of dividend, while the investors prefer current dividend payout to dividend delay which is realized in form of capital gain. As the consequence of this contradictory interest between the firm and the investors, the firm should apply beneficial dividend policy especially to the improvement of prosperity for those shareholders.

To find out the firm's financial performance, it can be seen from profitability rate made by the firm while performing its operational. Profitability in form of return on equity (ROE), return on assets (ROA), or return on investment (ROI) are important measurements to assess sound or unsound firm practices affecting investors to make decision. The higher gained profitability rate the higher financial performance reached by the firm, thus it will automatically attract investors to invest in the firm. If the profitability rate reached by the firm is high, the received return will do so. Appropriate profit divided into stakeholder is the profit which is divided after closing all of the firm's constant charges, i.e. bank interest and taxes.

Other than knowing the gained profitability rate from the firm's financial performance, it may be also seen based on Jakarta Composite Index/JCI (ID: IndeksHargaSahamGabungan/IHSG) and the amount of traded stocks. Otherwise, value of the firm can be seen based on market capitalization rate or transaction rate of its stocks. Then, the development of financial performance and value of the firm registered in Indonesia Stock Exchange/IDX (ID: Bursa Efek Indonesia/BEI) can be seen in the following Table 1.

Table 1. The Development of Financial Performance and Value of the Firm Registered in Indonesia Stock Exchange in 2008-2012

\begin{tabular}{ccccc}
\hline Year & JCI & $\begin{array}{c}\text { Number of Shares } \\
\text { (Sheets) }\end{array}$ & $\begin{array}{c}\text { Market Capitalization } \\
\text { (Million IDR) }\end{array}$ & $\begin{array}{c}\text { Transaction Value } \\
\text { (Million IDR) }\end{array}$ \\
\hline 2008 & 1,355 & $1,361,905$ & $1,926,372$ & $1,179,355$ \\
2009 & 2,534 & $1,340,558$ & $2,019,380$ & $1,182,333$ \\
2010 & 3,704 & $1,337,579$ & $3,243,770$ & $1,181,359$ \\
2011 & 3,822 & $1,203,550$ & $3,537,423$ & $1,223,441$ \\
2012 & 4,317 & $1,055,227$ & $4,084,714$ & $1,116,718$ \\
Average & 3,146 & $1,259,764$ & $2,962,332$ & $1,176,641$ \\
\hline
\end{tabular}

Source: Report of Securities and Exchange Commission (SEC) and Financial Institution, 2013 


\section{Macrothink}

Table 1 shows that the firm's Jakarta Composite Index (JCI) registered in Indonesia Composite Index from 2008 to 2012 increases every year, for example in 2011, this index increases by $12.95 \%$ in 2012. It indicates that the average rate of JCI in Indonesia Stock Exchange in 2008-2012 is closed at 3,146. Value of market capitalization also increases from 2008 to 2012 where its increase rate in 2012 is $15.47 \%$ from 2011 with average value by 2,962,332 every year for 5 years. However, if it is closely seen, recently, the number of shares outstanding every year, from 2008 to 2012 decreases, and the average number of shares outstanding every year is 1,259,764 sheets. Transaction value in Indonesia Stock Exchange also decreases, where in 2012, it falls into 5.37\% from 2011, and the average of transaction value is 1,176,641 per year. It means that financial performance of public firms registered in Indonesia Stock Exchange is falling down in 2012 compared to the previous years.

\section{Methods}

This study uses descriptive research and explanatory research. Data used herein is based on secondary data. Secondary data is the data obtained from documentation and financial report of each company as the object of the study, Indonesian Capital Market Directory (ICMD), Capital Market Statistic, or the other written reports taken from literature-based study, references, documentation, and the other printed media and also firm rules relevant to this study.

Data sampling is conducted by means of documentation, i.e. by learning documents, reports, and information related to the study. Population herein is all of companies registered in Indonesia Stock Exchange, by total number of 464 in 2012 which are divided into 34 sectors. Sample selection is conducted based on purposive sampling method in purpose to get representative sample in accordance with the determined sample criteria.

It uses Path Analysis model with program Amos version 18.

\section{Result}

\subsection{Evaluation of the Validity Data}

Data testing result by test on outliers data, data normality, and data linearity show that all of research variables either independent variable, intervening variable, or dependent variable is valid to be analyzed in this study.

\subsection{Model Conformance Testing Results}

Based on empiric model used in this study, i.e. Path Analysis with software AMOS version 18, hypothesis testing can be done through path coefficient testing in structural equation model. 


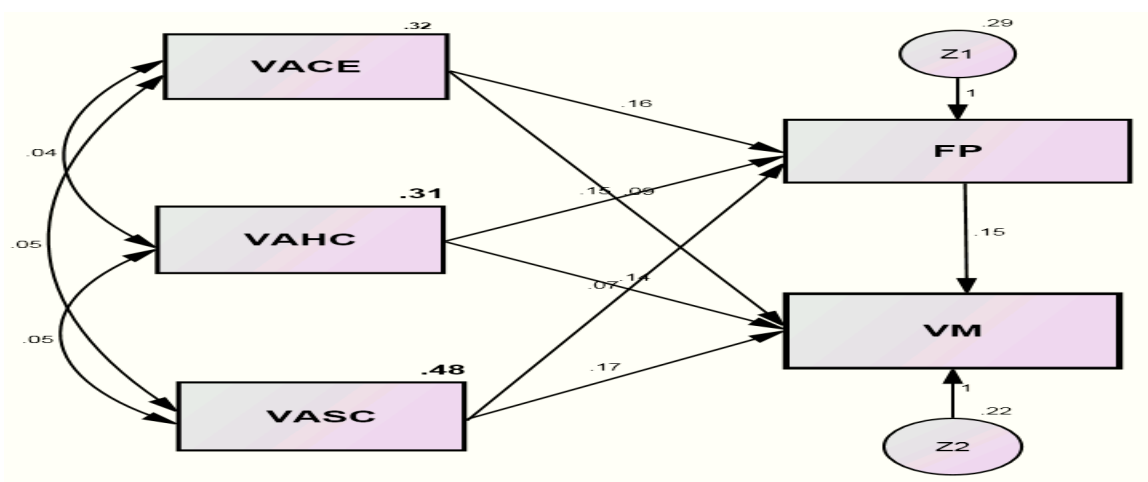

Figure 1. Hypothesis Testing through Coefficient Testing

The following table is hypothesis testing by looking at $\mathrm{p}$ value. If $\mathrm{p}$ value is smaller than 0.05 , relation or influence of inter-variable is significant. Otherwise, there is an explanation on direct effect indicating that there is direct and positive effect on inter-variable, and indirect effect indicating that there is positive effect occurred indirectly on inter-variable, and also total effect where the latter is the accumulation of direct and indirect effect on every analyzed variables.

Table 2. Hypothesis Testing

\begin{tabular}{|c|c|c|c|c|c|c|c|c|}
\hline \multirow[b]{2}{*}{ HIP } & \multicolumn{3}{|c|}{ Variable } & \multirow[b]{2}{*}{$\begin{array}{l}\text { Direct } \\
\text { Effects }\end{array}$} & \multirow[b]{2}{*}{$\begin{array}{l}\text { Indirect } \\
\text { Effects }\end{array}$} & \multirow[b]{2}{*}{ Total Effects } & \multirow[b]{2}{*}{ P-Value } & \multirow[b]{2}{*}{ Details } \\
\hline & $\begin{array}{c}\text { Independent } \\
\text { Variables }\end{array}$ & $\begin{array}{c}\text { Intervening } \\
\text { Variables }\end{array}$ & $\begin{array}{c}\text { Dependent } \\
\text { Variables }\end{array}$ & & & & & \\
\hline $\mathrm{H} 1$ & $\begin{array}{l}\text { Value Added Capital } \\
\text { Employed (VACE) }\end{array}$ & $\begin{array}{l}\text { Financial } \\
\text { Performance } \\
\text { (FP) }\end{array}$ & - & 0.116 & 0.000 & 0.116 & 0.000 & Significant \\
\hline H2 & $\begin{array}{l}\text { Value Added Human } \\
\text { Capital (VAHC) }\end{array}$ & $\begin{array}{l}\text { Financial } \\
\text { Performance } \\
\text { (FP) }\end{array}$ & - & 0.024 & 0.000 & 0.024 & 0.058 & Insignificant \\
\hline H3 & $\begin{array}{l}\text { Value Added } \\
\text { Structural } \\
\text { Capital (VASC) }\end{array}$ & $\begin{array}{l}\text { Financial } \\
\text { Performance } \\
\text { (FP) }\end{array}$ & - & 0.051 & 0.000 & 0.051 & 0.046 & Significant \\
\hline $\mathrm{H} 4$ & $\begin{array}{l}\text { Value Added Capital } \\
\text { Employed (VACE) }\end{array}$ & - & $\begin{array}{l}\text { Value of the } \\
\text { Firm } \\
(\mathrm{VF})\end{array}$ & 0.070 & 0,007 & 0.077 & 0.025 & Significant \\
\hline H5 & $\begin{array}{l}\text { Value Added Human } \\
\text { Capital (VAHC) }\end{array}$ & - & $\begin{array}{l}\text { Value of the } \\
\text { Firm } \\
\text { (VF) }\end{array}$ & 0.042 & 0.004 & 0.046 & 0.053 & Insignificant \\
\hline H6 & $\begin{array}{l}\text { Value Added } \\
\text { Structural } \\
\text { Capital } \\
\text { (VASC) }\end{array}$ & - & $\begin{array}{l}\text { Value of the } \\
\text { Firm } \\
(\mathrm{VF})\end{array}$ & 0.226 & 0.003 & 0.229 & 0.000 & Significant \\
\hline H7 & $\begin{array}{l}\text { Financial } \\
\text { Performance (FP) }\end{array}$ & $\begin{array}{l}\text { Value of the } \\
\text { Firm } \\
(\mathrm{VF})\end{array}$ & - & 0.072 & 0.000 & 0.072 & 0.022 & Significant \\
\hline
\end{tabular}




\section{Discussion}

\subsection{The Influence of VACE on the Financial Performance and Value of the Firm}

This test result is in line with hypothesis stating that value added capital employed give positive and significant effect on the financial performance and value of the firm. It is proved by regression coefficient with positive value $(0.116$ for financial performance and 0.070 for value of the firm), and its significance value is 0.00 for financial performance and 0.025 for value of the firm. Indirectly, this value added capital employed also gives positive effect on value of the firm by 0.007 . It indicates that the direct effect from value added capital employed is larger compared to the indirect effect on value of the firm. This condition shows that the larger amount of value added capital employed (VACE) will affect the improvement of financial performance and value of the firm registered in Indonesia Stock Exchange. Company having the larger amount of physical capital will get the better return on equity (ROE) where value of the firm, at last, will be higher. Likewise, with the higher value added of capital employed (VACE), company tends to have higher financial performance. Pursuant to market perception, this condition reflects a better performance or it gives a good signal to investor. Higher VACE along with an increase in value of firm gives an overview that if the firm's sales increases, the firm's profit will also increase.

Firer and Williams (2003), Ming Chin et al. (2005), Tan et al. (2007) also conducts a research on the influence of value added of capital employed (VACA) on financial performance and value of the firm; they found that it gives positive and significant effect.It is in accordance with the findings found by Daniel et al. (2011), Reza GharoieAhangar (2011), Mu Shun Wang (2011), and Wasim et al. (2012) and the same conclusion is also reported by Nora and Shiddiq (2012) and OmidAmri and Abdoli (2012).

\subsection{The Influence of VAHC on the Financial Performance and Value of the Firm}

Test result shows that value added human capital (VAHC) directly affects positively and insignificantly financial performance. It is different from the findings found by Firer and Williams (2003), Ming Chin et al. (2005), and Mu Shun Wang (2011). This finding is contradicted a hypothesis stating that value added human capital (VAHC) gives positive and significant effect on financial performance. It is proved by regression coefficient with positive value of 0.024 and significance value of 0.058 . Similar to value added human capital (VAHC), i.e giving direct positive and insignificant effect on value of the firm, this value is proved by regression coefficient of 0.042 and its significance value which is more than 0.05 is 0.053 . Indirectly, value added human capital (VAHC) also gives positive effect on value of the firm by 0.004. It means that the direct effect from value added human capital (VAHC) is higher than its indirect effect on value of the firm. If there is one point VAHC on rise, it causes financial performance increase measured by return on equity (ROE) by 0.024 and value of the firm (M/B) increase by 0.042 . This condition indicates that the higher value added human capital (VAHC) affects increase of financial performance and value of the firm as noted in Indonesia Stock Exchange, although the increase between VAHC and financial performance and value of the firm is not significant. 
Research findings on positive and insignificant effect of value added human capital (VAHC) on financial performance and value of the firm supports the findings found by Nova Lili and DidikArdiyanto (2012).However, this finding does not agree with the previous findings conducted by AbbasaliDaryaee et al. (2011), Farah and Arief (2006), and Olayinka and Uwalomwa (2011) and either by Reza GharoieAhangar (2011), OmidAmri\&MohamadrezaAbdoli (2012), and Sayed AlirezaMosavi et al. (2012) showing that value added human capital does not affect the firm's financial performance.

\subsection{The Influence of VASC on the Financial Performance and Value of the Firm}

Test result shows that value added structural capital (VASC) affects positively and significantly financial performance and value of the firm. This test result corresponds to hypothesis stating that value added structural capital directly gives positive and significant effect on financial performance and value of the firm. It is proved by regression coefficient with positive value ( 0.051 for financial performance and 0.226 for value of the firm), and its significance value is 0.046 for financial performance and 0.00 for value of the firm. Indirectly, value added structural capital (VASC) also gives positive effect on value of the firm by 0.003 . It means that direct effect from value added structural capital (VASC) is higher than indirect effect on value of the firm. It there is 1 point VASC on rise, it causes financial performance (ROW) increase by 0.051 and value of the firm (M/B) increase by 0.226 . This condition shows that the higher value added structural capital (VASC) will affect the increase of financial performance and value of the firm as noted in Indonesia Stock Exchange.

This research is conducted by Firer and Williams (2003), Ming Chin et al. (2005), and Tan et al. (2007) who conclude that value added structural capital (VASC) gives positive and significant effect on financial performance and value of the firm based on the findings.It is also reported by Stewart (1997), Bontis (2001), Olayinka and Uwalomwa (2011), Mu Shun Wang (2011), and Laila Asadi (2012). However, this finding is not in accordance with the findings found by Farah and Arief (2006) indicating that value added structural capital (VASC) gives negative and insignificant effect on financial performance and value of the firm.

\subsection{The Influence of Financial Performance on Value of the Firm}

Test result in this study corresponds to research hypothesis, i.e. by pointing out that financial performance gives positive and significant effect on value of the firm. It is proved by regression coefficient in positive value by 0.072 and significance value by 0.022 . It means that the higher financial performance reached by the company, the higher value of the firm as noted in Indonesia Stock Exchange.

It corresponds to the findings conducted by Nova Lili and DidikArdiyanto (2012) finding that financial performance gives positive and significant effect on value of the firm. However, this finding contravenes the findings found by Niyanti and Mutmainah (2012) where the financial performance is measured by return on assets (ROA), while value of the firm is measured by tobin's q. The finding shows that financial performance gives positive and significant effect on value of the firm. 


\subsection{Research Limitations}

1. There are some limitations in this study that this study:

2. Only uses data in 1 year period (in 2012) and it does not consider time lag factor.

3. Only uses market value to book value (M/B) value as the indicator of value of the firm.

4. Only uses return on equity (ROE) as the indicator of the company's financial performance.

5. Does not separate institutional ownership owned by foreigner and domestic ownership (national).

\section{Conclusions and Recommendations}

Based on the previous analysis result and discussion, it can be concluded as follows:

1. Each of intellectual capital components consisting of value added capital employed (VACE) and value added structural capital (VASS) gives positive and significant effect on the firm's financial performance. While the value added human capital (VAHC) gives positive and insignificant effect on the firm's financial performance as noted in Indonesia Stock Exchange.

2. Each of intellectual capital components consisting of value added capital employed (VACE) and value added structural capital (VASC) directly or indirectly gives positive and significant effect on value of the firm. While the value added human capital (VAHC) gives positive and insignificant effect on value of the firm as noted in Indonesia Stock Exchange.

3. Financial performance gives positive and significant effect on value of the firm registered in Indonesia Stock Exchange.

Based on the proposed conclusion above, the following is some suggestion:

1. For those companies registered in Indonesia Stock Exchange, it is very important to have investment in efficient intellectual capital if they want to raise the financial performance because efficient intellectual capital will have a strong competitiveness that will encourage the company to keep moving in the future.

2. As long as possible, those companies registered in Indonesia Stock Exchange need to raise market reaction and credence of investors to the firm by keep paying attention to non-physical asset utilization that reflects intangible value other than looking closely to physical asset utilization that reflects the firm's tangible value. 


\section{References}

Abbasali Daryaee, Abdolah Pakdel, Kamal Easapour, \& Malek Mohamadi Khalaflu. (2011). Intellectual Capital, Corporate Value and Corporate Governance (Evidence From Tehran Stock Exchange). Australian Journal of Basic and Applied Sciences, 5(12), 821-826.

Bontis, N. (1998). Intellectual Capital: An Exploratory study that Develops Measures and Models. Management Becision, 36(2), 63-76. http://dx.doi.org/10.1108/00251749810204142

\& J. Fitz-enz. (2002). Intellectual capital ROI: a causal map of humancapital antecedents and consequents. Journal of Intellectual Capital, 3(3), 223-47.

W.C.C. Keow, S. Richardson. (2000). Intellectual capital and business performance in Malaysian industries. Journal of Intellectual Capital, 1(1), 85-100.

Farah Margaretha, \&Arief Rakhman. (2006). Analisis Pengaruh Intelectual Capital Terhadap Market Value dan Financial Performance Perusahaan Dengan Metode Value Added Intelectual Coefficient. Junal Bisnis dan Akuntansi, 8(2), 199-217.

Firer, S., \& Williams, S.M. (2003).Intellectual capital and traditional measures of corporate performance. Journal of Intellectual Capital, 4(3), 348-360. http://dx.doi.org/10.1108/14691930310487806

Leila Asadi. (2012). Investigating the Effect of Intellectual Capital on the Value Creation of Companies Listed in Tehran Stock Exchange. Science Road Publishing Corporation, Trends in Social Science, 2(1), 2-12.

Ming Chin Chen, Shu Ju Cheng, \& Yuhchang Hwang. (2005). An Empirical Investigation of the Relationhip Between Intellectual Capital and Firms Market Value and Financial Performance. Journal of Intellectual Capital, 6(2), 159-176. http://dx.doi.org/10.1108/14691930510592771

Mu Shun Wang. (2011). Intellectual Capital and Firm Performance.Annual Conference on Innovations in Business \& Management. London: UK. 2011, 1-26.

Olayinka Marte Uadiale, \& Uwalomwa Uwugbe. (2011). Intellectual Capital and Business Performance: Evidence from Nigeria. Interdisciplinary Journal of Research in Business, 1(10), 49-56.

Omid Amri, \& Mohamadreza Abdoli. (2012). The Relationship Between Intellectual Capital and Performance of Companies (A Case Study of Cement Companies Listed in Tehran Stock Exchange). World Applied Sciences Journal, 20(4), 520-526.

Petty, P., \& J. Guthrie. (2000). Intellectual Capital Literature Review: Measurement, Reporting and Management. Journal of Intellectual Capital, 1(2), 155-175. http://dx.doi.org/10.1108/14691930010348731

Reza Gharoie Ahangar. (2011). The Relationship Between Intellectual Capital and Financial Performance: An Emperical Investigation in an Iranian Company.African Journal of 
Business Management, 5(1), 88-95.

Seyed Alireza Mosavi, Shekoufeh Nekoueizadeh, \& Mahnoosh Ghaedi. (2012). A Study of Relations Between Intellectual Capital Components, Market Value and Finance Performance. African Journal of Business Management, 6(4), 1396-1403.

Stewart, T.A. (1997). Intellectual Capital: The Wealth of New Organisations. Nicholas Brealey Publishing: London.

\section{Copyright Disclaimer}

Copyright reserved by the author(s).

This article is an open-access article distributed under the terms and conditions of the CreativeCommons Attribution license (http://creativecommons.org/licenses/by/3.0/). 